\title{
The Quantity Theory of Money: An Assessment of its Real Linchpin Prediction
}

\author{
Claude Hillinger \\ Bernd Süssmuth
}

\author{
CESIFO WORKING PAPER NO. 2995 \\ CATEGORY 7: MONETARY POLICY AND INTERNATIONAL FinANCE \\ MARCH 2010
}

An electronic version of the paper may be downloaded

- from the SSRN website:

- from the RePEc website:

- from the CESifo website:

www.SSRN.com

Www.RePEc.org

www.CESifo-group.org/wp 


\title{
The Quantity Theory of Money: An Assessment of its Real Linchpin Prediction
}

\begin{abstract}
This study approaches the Quantity Theory of Money at a conceptual level, asking how it can be most reasonably interpreted and quantitatively assessed. The resulting approach is straightforward. Unlike studies relying on other methods we find evidence of its linchpin prediction that is not limited to periods of high inflation.
\end{abstract}

JEL-Code: B22, E31, E41, E52.

Keywords: quantity theory of money.

Claude Hillinger

University of Munich

hillinger@Imu.de
Bernd Süssmuth

University of Leipzig

suessmuth@wifa.uni-leipzig.de 


\section{INTRODUCTION}

The quantity theory of money (QTM) is the oldest quantitative relationship that has been considered in economics. It also has the longest history of investigation by quantitative methods. In spite of all of the intellectual and empirical efforts that have been devoted to it, the validity of the QTM has remained controversial and the role that it has played in macroeconomic theory and policy has fluctuated largely over time. We believe that this unsatisfactory performance is due to deficiencies in how the empirical work on the QTM was done.

The simplest form of the QTM, also known as the Cambridge equation ${ }^{1}$ is

$$
M=k Y \text {, }
$$

where $M$ is the money stock, $Y$ is nominal expenditure, in empirical applications usually identified with nominal GDP ${ }^{2}$. A more usual form of the quantity equation is

$$
M=k P y,
$$

where $P$ is a deflator and $y$ real expenditure. Taking logarithms and letting a dot stand for logarithmic differentiation, we obtain in proportional rates of change

$$
\dot{M}=\dot{k}+\dot{P}+\dot{y} .
$$

Empirical work on the QTM has invariably been done in relation to (3) because it contains the variables of greatest interest, $\dot{M}$ and $\dot{P}$. Usually, episodes of high inflation were selected for these studies since the large variations in $\dot{M}$ and $\dot{P}$ could be expected to dwarf variations in $\dot{k}$ and even in $\dot{y}$. Studies of this type have found a rough equality of $\dot{M}$ and $\dot{P}$ and interpreted this as a confirmation of the QTM. The collection edited by Capie (1991) offers good examples. The exclusive concentration on periods of high, or at least moderately high, periods of inflation is somewhat unsatisfactory since nothing in the conceptual derivation of the QTM suggests such a limitation.

More recent studies focus on testing an explicit null hypothesis that is taken to be the implication of the QTM: It is that $k$ must be constant, or equivalently that $\dot{M}=\dot{P}+\dot{y}$. As

\footnotetext{
${ }^{1}$ So named because it first appeared in an article by Cambridge economist A. C. Pigou (1917). The constant is referred to as 'Cambridge k'.

${ }^{2}$ In the original discussions of the QTM, $Y$ was taken to be total expenditure, including payments for goods that are traded many times. It was this conceptualization that led to the definition of $v=1 / k$ as 'velocity', i.e. the average number of times that a unit of currency changes hands in the course of transactions.
} 
representative of this approach we take the papers of Moroney (2002) and Brumm (2005). Both use the same dataset of 81 countries over the period 1980-1993. Moroney finds:

The quantity theory predicts inflation with stunning accuracy for all countries experiencing actual inflation greater than $60 \%$ but less accurately of 16 OECD countries characterized by low money growth. These results strongly suggest that high long-run inflation is driven by equally high long-term money growth. The relation is essentially one for one. But to forecast inflation within an important group of countries marked by low long-run money growth, the one-for-one relation breaks down.

A fundamental criticism that we level at both papers is their focus on testing an exact version of the QTM. In our formulation this is equivalent to asserting the constancy of the Cambridge coefficient. We argue that this assumption, derived from a thought experiment, is implausible when applied to an empirical time series. Moroney had falsely thought that he could confirm this version. Brumm was able to get a significant result, but only in a more complex model incorporating a dependence of real GDP growth on money growth. Both papers thus fail in validating a traditional form of the QTM.

We view the empirical work done on the QTM based on equation (3) as being methodologically flawed. Differentiation of the theoretical equation leads to the requirement that series are logarithmically differentiated, thereby creating an instability that must in turn be reduced by averaging the differenced observations over long periods. The differentiation is in effect reversed by a crude ad hoc form of numerical integration. Ultimately the issue is the stability of $k$, and this can be investigated much more directly and efficiently in relation to (1) than in relation to $(3)$.

A further problem with the standard approach is that the statistical agencies have not employed methods for computing inflation that can be justified from a theoretical point of view (Hillinger, 2008). The decomposition (2) of nominal expenditure is therefore also problematic.

\section{NEW EVIDENCE ON THE QUANTITY THEORY}

The usefulness of the theory as an empirical regularity, rather than a mere tautology, depends on the stability of $k$. Suppose we have the time series $M^{1}, \ldots, M^{T}, Y^{1}, \ldots, Y^{T}$ and the derived coefficients $k^{1}, \ldots, k^{T}$. The simplest measure of stability is simply the ratio

$$
\kappa=k^{T} / k^{1} .
$$

Relative to the usual comparison of the growth rate of the money stock with inflation, this test has several decisive advantages: a. Short-run variations in $k$ are automatically averaged 
out. b. Even at low inflation rates, the variations in $M$ and $Y$ will be substantial over the entire range of a longer time series. c. The usual manipulations of the data, specifically the averaging of growth rates, are avoided.

The statistic (4) does not eliminate transitory effects completely, since these are still contained in $k^{1} ; k^{T}$, but it is to be expected that these effects will be small relative to systematic changes in $M$ and $Y$. An improved statistic can be obtained by fitting a regression line of the $k^{t}$ against $t$. For each $t$, the point $\hat{k}^{t}$ on the regression line is an estimate of the equilibrium value of $k$ at $t$. An improved estimate is therefore

$$
\hat{\kappa}=\frac{\hat{k}^{T}}{\hat{k}^{1}}
$$

In order to analyze (5) we draw data from NYU's Development Research Institute (DRI) Global Development Network Growth Database Macro Time Series. ${ }^{1}$ The series originate from the World Bank's Global Development Finance (GDF) \& World Development Indicator (WDI) series. Our focus is on M2 (money and quasi money) as a percent of nominal GDP time series. We rely on a subsample of the raw DRI series for which we have reliable data that comprise 125 countries for a maximum period of 44 years from 1960 to 2003.

Figure 1 shows the histogram for our estimates of equation (5). Both mean and median lie slightly above 1.5 , the modal value is a clear-cut 1.0 .

As our measure of stability we take the average rate of change of $k$ over the interval. It is derived from:

$$
\hat{\kappa}=\frac{\hat{k}^{T}}{\hat{k}^{1}}=\exp T \dot{k} .
$$

The average growth rate of $k$ is therefore given by

$$
\dot{k}=\frac{\ln \hat{\kappa}}{T} .
$$

Figure 2 provides a histogram of the distribution of $\dot{k}$ in our sample. The mean is 0.016 , the median 0.015 , the std. dev. is 0.028 and the associated range around the mean is $(-0.012$, 0.044). We interpret these values as showing that $k$ is sufficiently stable for the purpose of monetary policy. This will be elaborated in the next section.

\footnotetext{
${ }^{1}$ http://www.nyu.edu/fas/institute/dri.
} 


\section{IMPLICATIONS FOR MONETARY POLICY}

For the purpose of this section we reinterpret equation (3) as

$$
\dot{m}^{r}=\dot{p}^{d}+E \dot{y}+E \dot{k},
$$

where $\dot{m}^{r}$ is the long run money growth rate required to validate the rhs of $(8), \dot{p}^{d}$ is the desired long run inflation rate, $E \dot{y}$ is the expected long term growth rate of the real economy and $E \dot{k}$ is the expected long term growth rate of the Cambridge constant. If no suitable estimate is available, the last term can be set equal to zero. The empirical results of the previous section show that when this is done, the resulting error in $\dot{m}^{r}$ and hence in $\dot{p}^{d}$ will be 1.6 percent in the mean and in the range $(-1.2,4.4)$ percent for around two thirds of all countries. Furthermore, it should be possible to reduce these errors substantially by basing the estimate of $\dot{m}^{r}$ on econometric estimates of $E \dot{k}$ such as those of the present paper.

Over the past decades central banks, particularly in the United States, have pursued policies for the active short-term stabilization of the macroeconomy. They thereby hindered the natural process of using recessions to rectify the imbalances created during the preceding boom. Imbalances could therefore build up over several cycles, resulting in the current deep financial/economic crisis. This experience, along with the stability of the QTM relationship that we have demonstrated, suggests a return to a Friedmanian position ${ }^{1}$ on monetary policy: The money supply should be expanded at a constant rate that in accordance with the QTM equation would yield the desired long-run inflation rate.

\section{CONCLUSION}

Empirical work in economics is too often done with a heavy load of prior commitments, either to some particular economic theory or to some specific econometric method. We have first of all approached the QTM at a conceptual level, asking how it can be most reasonably interpreted. Then we asked for the simplest possible way to quantify it. The resulting approach is straightforward, and in our view superior to methods that have thus far been employed. Unlike the usual methods, ours is not limited to periods of high inflation. In our sample of 125 countries, we found the QTM to be a relationship that is stable over long periods and therefore suitable for the conduct of long-range monetary policy.

\footnotetext{
${ }^{1}$ See Friedman $(1961,1968)$.
} 


\section{REFERENCES}

Brumm, Harold J. (2005), Money growth, output growth, and inflation: A reexamination of the modern quantity theory's linchpin prediction, Southern Economic Journal, 71(3), 661667.

Capie, Forrest H. (1991), Major Inflations in History, Edward Elgar.

Dwyer, Gerald P. Jr. (1998), Is money a leading indicator of inflation? Unpublished paper, Federal Reserve Bank of Atlanta.

Fischer, Stanley; Sahay, Ratna; Végh, Carlos A. (2002), Modern hyper-and high inflations, Journal of Economic Literature, XL, 3, 837-880.

Friedman, Milton (1961), The lag in effect of monetary policy, Journal of Political Economy, 69, 5, 447-466.

(1968), The role of monetary policy, American Economic Review, 58, 1-17.

Hillinger,Claude (2008), Measuring Real Value and Inflation. Economics E-Journal, Vol. 2, 20 Downloadable at:

http://www.economics-ejournal.org/economics/journalarticles/2008-20

Moroney, John R. (2002), Money growth, output growth, and inflation: Estimation of a modern quantity theory, Southern Economic Journal, 69, 2, 398-413. 


\section{APPENDIX: COUNTRIES IN THE GLOBAL DEVELOPMENT NETWORK GROWTH DATABASE (DRI, NYU)}

Albania, Algeria, Angola, Antigua and Barbuda, Argentina, Armenia, Aruba, Australia, Azerbaijan, (the) Bahamas, Bahrain, Bangladesh, Barbados, Belarus, Belize, Benin, Bhutan, Bolivia, Bosnia and Herzegovina, Botswana, Brazil, Bulgaria, Burkina Faso, Burundi, Cambodia, Cameroon, Canada, Cape Verde, Central African Republic, Chad, Chile, China, Colombia, Comoros, (Dem. Rep.) Congo, (Rep.) Congo, Costa Rica, Cote d'Ivoire, Croatia, Cyprus, Czech Republic, Denmark, Djibouti, Dominica, Dominican Republic, Ecuador, (Arab Rep.) Egypt, El Salvador, Equatorial Guinea, Eritrea, Estonia, Ethiopia, Fiji, Gabon, (the) Gambia, Georgia, Ghana, Grenada, Guatemala, Guinea, Guinea-Bissau, Guyana, Haiti, Honduras, (China) Hong Kong, Hungary, Iceland, India, Indonesia, (Islamic Rep.) Iran, Iraq, Israel, Jamaica, Japan, Jordan, Kazakhstan, Kenya, (Rep.) Korea, Kuwait, Kyrgyz Republic, Lao PDR, Latvia, Lebanon, Lesotho, Liberia, Libya, Lithuania, (China) Macao, FYR Macedonia, Madagascar, Malawi, Malaysia, Maldives, Mali, Malta, Mauritania, Mauritius, Mexico, (Fed. Sts.) Micronesia, Moldova, Mongolia, Morocco, Mozambique, Myanmar, Namibia, Nepal, Netherlands, Antilles, New Zealand, Nicaragua, Niger, Nigeria, Norway, Oman, Pakistan, Panama, Papua New Guinea, Paraguay, Peru, Philippines, Poland, Qatar, Romania, Russian Federation, Rwanda, Samoa, Sao Tome and Principe, Saudi Arabia, Senegal, Seychelles, Sierra Leone, Singapore, Slovak Republic, Slovenia, Solomon Islands, South Africa, Sri Lanka, St. Kitts and Nevis, St. Lucia, St. Vincent and the Grenadines, Sudan, Suriname, Swaziland, Switzerland, Syrian Arab Republic, Tajikistan, Tanzania, Thailand, Togo, Tonga, Trinidad and Tobago, Tunisia, Turkey, Turkmenistan, Uganda, Ukraine, United Arab Emirates, United States, Uruguay, Vanuatu, (RB) Venezuela, Vietnam, (Rep.) Yemen, Zambia, Zimbabwe 
Figure 1.

Distribution of $\kappa$

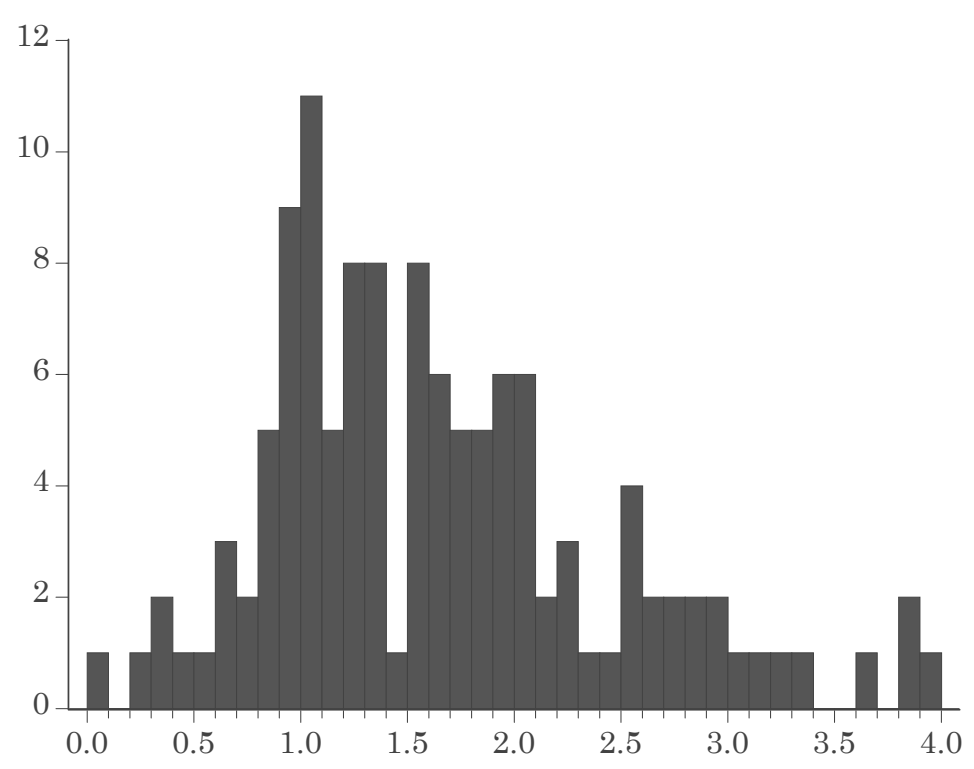

Figure 2.

Distribution of $\dot{k}$

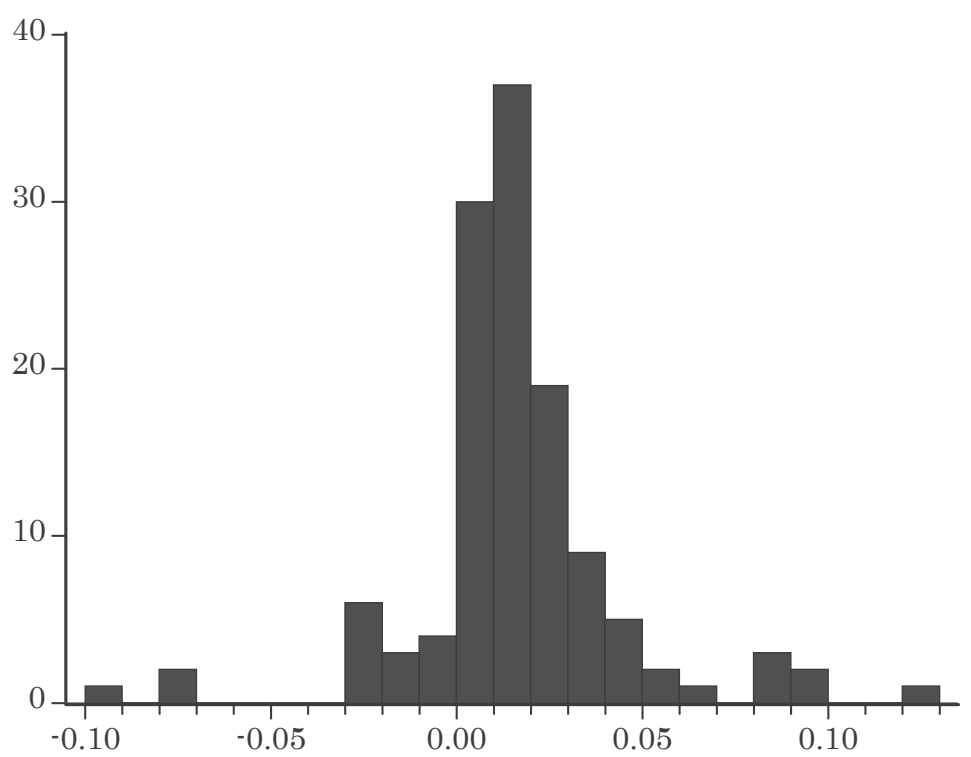




\section{CESifo Working Paper Series}

for full list see www.cesifo-group.org/wp

(address: Poschingerstr. 5, 81679 Munich, Germany, office@cesifo.de)

2929 J. Trent Alexander, Michael Davern and Betsey Stevenson, Inaccurate Age and Sex Data in the Census PUMS Files: Evidence and Implications, January 2010

2930 Stefan Krasa and Mattias K. Polborn, Competition between Specialized Candidates, January 2010

2931 Yin-Wong Cheung and Xingwang Qian, Capital Flight: China's Experience, January 2010

2932 Thomas Hemmelgarn and Gaetan Nicodeme, The 2008 Financial Crisis and Taxation Policy, January 2010

2933 Marco Faravelli, Oliver Kirchkamp and Helmut Rainer, Social Welfare versus Inequality Concerns in an Incomplete Contract Experiment, January 2010

2934 Mohamed El Hedi Arouri and Christophe Rault, Oil Prices and Stock Markets: What Drives what in the Gulf Corporation Council Countries?, January 2010

2935 Wolfgang Lechthaler, Christian Merkl and Dennis J. Snower, Monetary Persistence and the Labor Market: A New Perspective, January 2010

2936 Klaus Abberger and Wolfgang Nierhaus, Markov-Switching and the Ifo Business Climate: The Ifo Business Cycle Traffic Lights, January 2010

2937 Mark Armstrong and Steffen Huck, Behavioral Economics as Applied to Firms: A Primer, February 2010

2938 Guglielmo Maria Caporale and Alessandro Girardi, Price Formation on the EuroMTS Platform, February 2010

2939 Hans Gersbach, Democratic Provision of Divisible Public Goods, February 2010

2940 Adam Isen and Betsey Stevenson, Women's Education and Family Behavior: Trends in Marriage, Divorce and Fertility, February 2010

2941 Peter Debaere, Holger Görg and Horst Raff, Greasing the Wheels of International Commerce: How Services Facilitate Firms' International Sourcing, February 2010

2942 Emanuele Forlani, Competition in the Service Sector and the Performances of Manufacturing Firms: Does Liberalization Matter?, February 2010

2943 James M. Malcomson, Do Managers with Limited Liability Take More Risky Decisions? An Information Acquisition Model, February 2010 
2944 Florian Englmaier and Steve Leider, Gift Exchange in the Lab - It is not (only) how much you give ..., February 2010

2945 Andrea Bassanini and Giorgio Brunello, Barriers to Entry, Deregulation and Workplace Training: A Theoretical Model with Evidence from Europe, February 2010

2946 Jan-Emmanuel De Neve, James H. Fowler and Bruno S. Frey, Genes, Economics, and Happiness, February 2010

2947 Camille Cornand and Frank Heinemann, Measuring Agents' Reaction to Private and Public Information in Games with Strategic Complementarities, February 2010

2948 Roel Beetsma and Massimo Giuliodori, Discretionary Fiscal Policy: Review and Estimates for the EU, February 2010

2949 Agnieszka Markiewicz, Monetary Policy, Model Uncertainty and Exchange Rate Volatility, February 2010

2950 Hans Dewachter and Leonardo Iania, An Extended Macro-Finance Model with Financial Factors, February 2010

2951 Helmuth Cremer, Philippe De Donder and Pierre Pestieau, Education and Social Mobility, February 2010

2952 Zuzana Brixiová and Balázs Égert, Modeling Institutions, Start-Ups and Productivity during Transition, February 2010

2953 Roland Strausz, The Political Economy of Regulatory Risk, February 2010

2954 Sanjay Jain, Sumon Majumdar and Sharun W. Mukand, Workers without Borders? Culture, Migration and the Political Limits to Globalization, February 2010

2955 Andreas Irmen, Steady-State Growth and the Elasticity of Substitution, February 2010

2956 Bengt-Arne Wickström, The Optimal Babel - An Economic Framework for the Analysis of Dynamic Language Rights, February 2010

2957 Stefan Bauernschuster and Helmut Rainer, From Politics to the Family: How Sex-Role Attitudes Keep on Diverging in Reunified Germany, February 2010

2958 Patricia Funk and Christina Gathmann, How do Electoral Systems Affect Fiscal Policy? Evidence from State and Local Governments, 1890 to 2005, February 2010

2959 Betsey Stevenson, Beyond the Classroom: Using Title IX to Measure the Return to High School Sports, February 2010

2960 R. Quentin Grafton, Tom Kompas and Ngo Van Long, Biofuels Subsidies and the Green Paradox, February 2010 
2961 Oliver Falck, Stephan Heblich, Alfred Lameli and Jens Suedekum, Dialects, Cultural Identity, and Economic Exchange, February 2010

2962 Bård Harstad, The Dynamics of Climate Agreements, February 2010

2963 Frederick van der Ploeg and Cees Withagen, Is There Really a Green Paradox?, February 2010

2964 Ingo Vogelsang, Incentive Regulation, Investments and Technological Change, February 2010

2965 Jan C. van Ours and Lenny Stoeldraijer, Age, Wage and Productivity, February 2010

2966 Michael Hoel, Climate Change and Carbon Tax Expectations, February 2010

2967 Tommaso Nannicini and Roberto Ricciuti, Autocratic Transitions and Growth, February 2010

2968 Sebastian Brauer and Frank Westermann, A Note on the Time Series Measure of Conservatism, February 2010

2969 Wolfram F. Richter, Efficient Education Policy - A Second-Order Elasticity Rule, February 2010

2970 Tomer Blumkin, Yoram Margalioth and Efraim Sadka, Taxing Children: The Redistributive Role of Child Benefits - Revisited, February 2010

2971 Chang Woon Nam and Georg Wamser, Application of Regionally Varying Additionality Degrees in the Practice of EU Cohesion Policy, February 2010

2972 Ali Bayar, Frédéric Dramais, Cristina Mohora, Masudi Opese and Bram Smeets, Modeling Russia for Climate Change Issues, February 2010

2973 Magnus Söderberg, Informal Benchmarks as a Source of Regulatory Threat in Unregulated Utility Sectors, March 2010

2974 Piotr Wdowiński and Marta Malecka, Asymmetry in Volatility: A Comparison of Developed and Transition Stock Markets, March 2010

2975 Frans van Winden, Michal Krawczyk and Astrid Hopfensitz, Investment, Resolution of Risk, and the Role of Affect, March 2010

2976 Hyun-Ju Koh and Nadine Riedel, Do Governments Tax Agglomeration Rents?, March 2010

2977 Johann K. Brunner and Susanne Pech, Optimum Taxation of Bequests in a Model with Initial Wealth, March 2010

2978 Guglielmo Maria Caporale and Nicola Spagnolo, Stock Market Integration between three CEECs, Russia and the UK, March 2010 
2979 Florian Englmaier, Ales Filipi and Ravi Singh, Incentives, Reputation and the Allocation of Authority, March 2010

2980 Konstantinos Angelopoulos, George Economides and Apostolis Philippopoulos, What is the Best Environmental Policy? Taxes, Permits and Rules under Economic and Environmental Uncertainty, March 2010

2981 Frederick van der Ploeg, Rapacious Resource Depletion, Excessive Investment and Insecure Property Rights, March 2010

2982 Wolfram F. Richter and Christoph Braun, Efficient Subsidization of Human Capital Accumulation with Overlapping Generations and Endogenous Growth, March 2010

2983 Francesco Cinnirella, Marc Piopiunik and Joachim Winter, Why Does Height Matter for Educational Attainment? Evidence from German Pre-Teen Children, March 2010

2984 Bernard Van Praag, Well-being Inequality and Reference Groups - An Agenda for New Research, March 2010

2985 Francesca Barion, Raffaele Miniaci, Paolo M. Panteghini and Maria Laura Parisi, Profit Shifting by Debt Financing in Europe, March 2010

2986 Alexander Haupt and Magdalena Stadejek, The Choice of Environmental Policy Instruments: Energy Efficiency and Redistribution, March 2010

2987 John Komlos and Marek Brabec, The Trend of BMI Values among US Adults, March 2010

2988 Emanuele Massetti and Lea Nicita, The Optimal Climate Policy Portfolio when Knowledge Spills across Sectors, March 2010

2989 Helmut Rainer and Thomas Siedler, Family Location and Caregiving Patterns from an International Perspective, March 2010

2990 Toru Kikuchi and Ngo Van Long, A Simple Model of Service Offshoring with Time Zone Differences, March 2010

2991 Assaf Razin, Efraim Sadka and Benjarong Suwankiri, Migration and the Welfare State: Dynamic Political-Economy Theory, March 2010

2992 Bård Harstad, Buy Coal! Deposit Markets Prevent Carbon Leakage, March 2010

2993 Axel Dreher, Stephan Klasen, James Raymond Vreeland and Eric Werker, The Costs of Favoritism: Is Politically-driven Aid less Effective?, March 2010

2994 Sven Neelsen and Thomas Stratmann, Effects of Prenatal and Early Life Malnutrition: Evidence from the Greek Famine, March 2010

2995 Claude Hillinger and Bernd Süssmuth, The Quantity Theory of Money: An Assessment of its Real Linchpin Prediction, March 2010 